\title{
The Effect of Balimo (Zanthoxylum nitidum) Immersion Water On The Hematological Profile of White Rats (Rattus norvegicus) That Given Liquor (Ciu)
}

\author{
Panca Buana Wijaya*, Tyas Rini Saraswati, Silvana Tana, Sunarno, Erma Prihastanti \\ Department of Biologi, Faculty of Science and Mathematics, Universitas Diponegoro, \\ Jl. Prof Soedarto, SH, Tembalang. Semarang, Indonesia. \\ Corresponding author* \\ pancabuanawijaya@gmail.com
}

Manuscript received: 21 December, 2020. Revision accepted: 11 June, 2021. Published: 23 July, 2021.

\begin{abstract}
Consumption of liquor such as Ciu in excessive doses can cause a decrease in hematological status. Balimo stem is an alternative treatment to improve hematological status due to excessive alcohol consumption because it contains alkaloids, flavonoids, and other secondary metabolic compounds, that have functions as antioxidant effects. This study aims to examine and analyze the effect of Balimo immersion water on the hematological status of mice with the observed variables, namely the erythrocytes count, hemoglobin levels, hematocrit value, and total count of leukocytes in rats that had been given Ciu. The study used 20 Rattus norvegicus male rats which were divided into 4 groups. The data were analyzed using one-way ANOVA. The results showed no significant differences $(\mathrm{p}<0.05)$ on the Balimo immersion water treatment, but if it was seen from the difference in the mean data of each variable, it could still be seen the difference from each treatment. In this study, it can be concluded that Balimo immersion water was able to improve the hematological status of rats that had been given Ciu liquor with a $0,2 \mathrm{~mL}$ dose.
\end{abstract}

Keywords: Antioxidant; Balimo; Zanthoxylum Nitidu; Hematological status; Rattus norvegicus.

\section{INTRODUCTION}

Ciu is a traditional liquor of Banyumas and Bekonang regions, Sukoharjo. Ciu is made from fermented cassava or sticky rice, which produces ethanol and carbon dioxide with $\pm 30 \%$ ethanol (BPOM, 2014). The World Health Organization (WHO) also states that consuming liquor regularly can cause long-term diseases including hepatitis, tuberculosis, heart disease, cancer, cirrhosis of the liver, an increase in infectious diseases such as HIV / AIDS, and can even cause death (Hammer et al., 2018). Laboratory examinations of 179 respondents who have the habit of drinking liquor found that the hemoglobin levels, erythrocyte count, and the hematocrits value showed lower values compared to normal conditions, besides the data showed that the total count of leukocytes was higher than normal (Riany \& Rahmayanti, 2013).

Drunk liquor will undergo an absorption process in the digestive system, the absorption process occurs in the oral mucosa, stomach, and small intestine. Alcohol is absorbed through the walls of the stomach and intestines, then carried by the blood circulation to all organs in the body, especially the liver. Alcohol that has reached the liver then undergoes a series of metabolism (Katzung \& Trevor, 2015). Ethanol metabolism in the liver produces acetaldehyde (Wilson \& Matschinsky, 2020). Too much acetaldehyde makes acetaldehyde more toxic. The acetaldehyde in mitochondria will be synthesized again into triglycerides or fatty acids through an oxidation process (King, 2019). The increase in triglycerides that occurs causes a buildup of fat in the liver, it triggers fatty liver or steatosis and eventually becomes alcoholic liver cirrhosis (Shah, 2015).

Patients with alcoholic liver cirrhosis have abnormal hematological parameters, which lead to a tendency to bleeding, anemia, leukopenia, and thrombocytopenia (Lindseth, 2013). The main factors causing complications of bleeding that occur are reduced clotting factors due to liver cirrhosis and the destruction of blood cells resulting in abnormalities in the number of blood cells (Armitage, 2011). The progressive decrease in hemoglobin level in liver cirrhosis patients. Hematological abnormalities are often found in acute alcohol drinkers in the study (Jain et al., 2016). The direct effect of excessive alcohol consumption is the toxic effect on bone marrow, blood cell precursors, erythrocyte mature cells, and leukocytes. The indirect effect of alcohol consumption is nutritional deficiencies that can interfere with blood cell production (hematopoiesis) and the function of various blood cells, 
causing an increase in blood pressure or hypertension (Ifeannyi et al., 2014).

The Balimo plant (Zanthoxylum nitidum) is used by the Kanayatn Dayak tribe in Tapakng Village as a medicinal plant for traditional medicine (Raja and Hartana, 2017). Balimo plants are used to treat alcohol poisoning after drinking wine (Andasputra \& Julipin, 2011). The Balimo plant is also used as a medicine for a cough with phlegm and hemoptysis treatment (Sepsamli \& Jumari, 2019). Balimo plant (Zanthoxylum nitidum) is used to improve blood circulation, relieving blood stasis in traditional Chinese medicine. Phytochemical investigations showed the presence of alkaloids, flavonoids, and true amino acids in the bark of Zanthoxylum nitidum (Bhattacharya \& Zaman, 2009). These compounds have benefits as anti-viral, antiinflammatory, antioxidant, and anti-cancer activities (Van Nguyen et al., 2019).

Balimo stem is expected to be an alternative to improve hematological status due to consuming liquor because it contains flavonoids, alkaloids that have antiinflammatory and antioxidant effects that function to improve hematological status (Aiba et al., 2016). Antioxidants are compounds that can inhibit oxidation reactions by binding to free radicals and highly reactive molecules (Suryani et al., 2013). The mechanism of action of flavonoid compounds as antioxidants is to maintain erythrocytes, by inhibiting peroxidation of lipid peroxidation caused by $\mathrm{H}_{2} \mathrm{O}_{2}$ and preventing protein degradation and hemolysis (Yousif et al., 2012). Flavonoids play an important role in regulating blood vessel health, namely maintaining maximum cardiac function (Catherine et al., 2015).

Based on the background above, to determine the effect of compounds in plants Balimo (Zanthoxylum nitidum), it will do the research and observation of the hematological status of male rats (Rattus norvegicus) who had been treated with alcohol and then given Balimo (Zanthoxylum nitidum) immersion water.

\section{MATERIALS AND METHODS}

\section{Research Ethics}

This study has received ethical clearance from the Ethics Commission for Health and Medical Research, Faculty of Medicine, Diponegoro University Semarang No. 164 / EC / H / KEPK / FK-UNDIP / XII / 2019.

\footnotetext{
Research Design and Research Locations

Research on the effect of Balimo (Zanthoxylum nitidum) stem immersion water on the hematological status of rats that have been given liquor (Ciu) was carried out in animal cages, and Animal Structure and Function Laboratory, Department of Biology, FSM-UNDIP. This study used 20 male rats (Rattus norvegicus) which were divided into 4 treatment groups, including:
}

A0: represents Rattus norvegicus control,

A1: represents cirrhosis Rattus norvegicus that given Ciu for 2 weeks at a dose of $0.2 \mathrm{~mL}$,

A2: represents cirrhosis Rattus norvegicus by giving Balimo immersion water (Ciu for 2 weeks and $50 \%$ Balimo immersion water for 2 weeks with a dose of $0.2 \mathrm{~mL}$ each),

A3: represents cirrhosis Rattus norvegicus with Balimo immersion water (Ciu for 4 weeks along with $50 \%$ Balimo immersion water for 2 weeks with a dose of $0.2 \mathrm{~mL}$ each).

Each treatment was repeated 5 times. Treatment for 2 weeks of acclimation and 4 weeks of treatment.

\section{Tools and Materials}

The tools used in this study include 35 sets of mouse cages, wire caps, food and drink containers, gloves, feeding bowls, sprayers, syringes, sonde, measuring cups, analytical scales, paraffin tubs, surgical instruments, EDTA tubes, dropper pipettes, hemometer sahli, Sahli pipette, aspirator, erythrocyte pipette, leukocyte pipette, microscope, object-glass, object glass cover, counters, cameras and counting booths improved Neubauer, centrifuge, hematocrit tube, microhematocrit reader. The materials used in this study included 35 male rats (Rattus norvegicus) 60 days old, standard organic feed, rice husks, drinking water, Balimo immersion water, detergent, distilled water, 39\% liquor (Ciu), 70\% alcohol, $0.1 \mathrm{~mL}$ HCL, Hemotoxin-Eosin dye, Hayem's solution, Turk solution, chloroform, glass objects, and blood samples.

\section{Making The Balimo Immersion Water}

Making Balimo immersion water is done by cutting the Balimo stem with a size of $0.5 \mathrm{~cm}$, then weighing it using $1 \mathrm{~g}$ of analytical scales and put in $10 \mathrm{~mL}$ of $36^{\circ} \mathrm{C}$ warm water stored in a tightly closed glass bottle and left for 3 days. The dosage levels is determined based on according to the ethical commission which has been converted based on the dose to humans and the determination of the concentration is determined based on the results of preliminary tests that are previously recognized.

\section{Blood Data Collection and Observation}

Hematological status data were obtained, then observed appropriately based on variables, such as:

\section{Erythrocyte Count}

Observation of the erythrocytes count was carried out using a microscope, improved Neubauer Hemocytometer counting chamber, erythrocyte pipette and aspirators, counters, hayem solution, aquades. Observations were carried out by observing and counting erythrocyte cells using a microscope, improved Neubauer counting chamber using the 5-square 
technique in the large square in the middle of the counting chamber, then the count of all erythrocyte cells in the five squares multiplied by 5000 (Oktiyani et al., 2017).

\section{Hemoglobin Levels}

Hemoglobin levels are observed with hemometer sahli method, by equating blood color on the color indicator (block comparator) in hemometer sahli, then calculated the existing high blood fluid in the tube hemometer sahli, aquades supplemented by the addition dropwise (A'tourrohman, 2020)

\section{Hematocrit Value}

Observation of the hematocrit value is carried out on blood in a centrifuge then the blood is fed into the microhematocrit reader or using the hematocrit value formula (Nurrahman \& Mariyam, 2019).

\section{Total Count of Leukocytes}

Observation of the total count of leucocytes was carried out using a microscope, counting booth improved Neubauer, leucocyte pipette and aspirator, counter, Turk solution, and distilled water. Observations were made by observing and counting leukocyte cells using a microscope, an improved Neubauer counting chamber in the five boxes located diagonally in 4 large squares in the corner of the counting room, the results were $\mathrm{x} 50$ cells / $\mathrm{mm}^{3}$ of blood (Bakhri, 2018).

\section{Data analysis}

Hematological status data that had been observed were then analyzed using analysis of variance (ANOVA) using a completely randomized design with 4 treatments and five replications (Gomez, 2005).

\section{RESULTS AND DISCUSSION}

The results of the statistical analysis of the effect of Balimo (Zanthoxylum nitidum) stem immersion water on the hematological status of rats (Rattus norvegicus) given liquor (Ciu). Based on the statistical analysis test using the one-way Analysis of Variance (ANOVA) test with a confidence level of $95 \%$.

Based on the results of data analysis using Anova, the effect of Balimo stem immersion water (Zanthoxylum nitidum) on the hematological status includes the erythrocytes count, hemoglobin levels, hematocrit values, and the total count leukocytes of white rat (Rattus norvegicus) which have been given Ciu shows no different results. real or ( $\mathrm{p}>0.05)$

Hematological status includes the erythrocytes count, hemoglobin levels, hematocrit values, and the total count leukocytes of white rat (Rattus norvegicus) which are not different due to several factors, including the length of time given treatment in all groups is still too short, which causes the treatment effect has not reached an acute point. Also, the body's immune system can maintain a state of hematological status, especially in mice when they are 6 weeks old, so that the mice can restore the state of hematological status. Guyton \& Hall (2014) states that the body has a defense system that can maintain and improve the condition of the body that is experiencing disorders.

\section{Erythrocyte Count}

The results of statistical tests based on the mean erythrocytes count of rats in the treatment groups A1, A2, A3 when compared with treatment A0 (control) showed a significant value above $0.05(\mathrm{p}>0.05)$ or the results were not significantly different. The results of the analysis of the number of erythrocytes still change based on the group and can be seen in the graph (Figure 1).

\section{Erythrocyte Count $(\times 106 / \mu \mathrm{L})$}

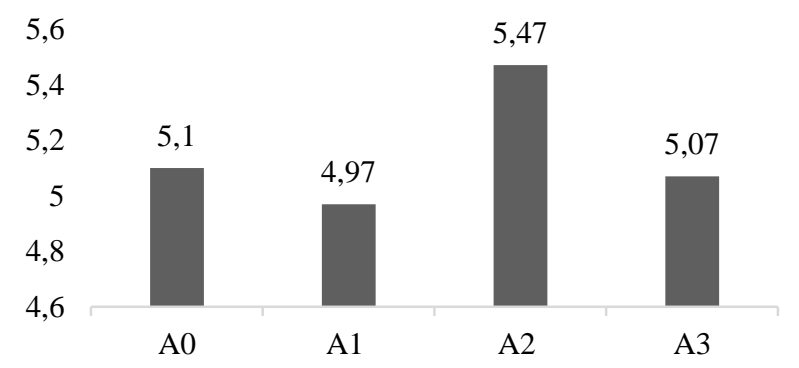

Figure 1. Erythrocyte Count.

The average number of erythrocytes when compared with the A0 treatment group, the erythrocytes count in group A1 decreased due to the toxicity effect of the alcohol content in Ciu drinks, resulting in damage to erythrocyte blood cells and suppression of erythrocyte formation (erythropoiesis) which occurs due to ethanol compounds scattered in the blood vessels and spinal cord.

The erythrocytes count in group A2 increase because treatment of A2 was able to inhibit free radicals that interfere with the formation of blood cells, and flavonoid and alkaloid compounds can also stimulate the central nerve, which stimulates the spinal cord so that the formation of red blood cells increases. The formation of red blood cells is not disturbed and will continue to form blood cells in the bone marrow, so the erythrocytes count can increase and tends to increase the hematological status of the A2 treatment group mice.

The erythrocytes count in group A3 has decreased and then increased because A3 approaches A0, this is because the erythrocytes count in group A3 has increased again and tends to maintain the erythrocytes count by protecting and repairing damage to blood cells from free radicals due to the presence of flavonoids and alkaloids that function as antioxidants in Balimo immersion water. Flavonoid and alkaloid compounds 
can also stimulate the central nervous system, which stimulates the spinal cord so that the formation of red blood cells increases.

Hartono et al., (2019), states that alcoholic drinks can have a toxic effect on bone marrow which causes suppression of blood production and abnormal blood structure so that the erythrocytes count is reduced. Stanley, et al. (2014) explained that alkaloid and flavonoid compounds act as antioxidants which can play a role in preventing oxidative stress due to exposure to free radicals.

\section{Hemoglobin Levels}

The results of statistical tests based on the mean hemoglobin levels of rats in the treatment groups A1, A2, A3 when compared with treatment A0 (control) showed a significant value above $0.05(p>0.05)$ or the results were not significantly different. The results of the analysis of hemoglobin levels continued to change based on groups and can be seen in graphs (Figure 2).

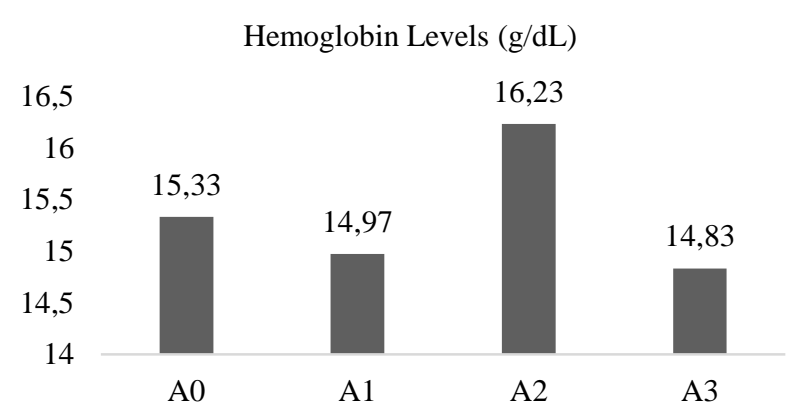

Figure 2. Hemoglobin Levels.

The average hemoglobin level when compared with the A0 treatment group, the hemoglobin level of group A1 decreased because it was caused by the toxic effect of ethanol compounds that spread in the body, both in the bone marrow and blood vessels due to giving Ciu for 2 weeks, without water treatment. Balimo immersion water. This causes damage to erythrocyte blood cells and reduces or destroys the ability of erythrocyte blood cells to synthesize hemoglobin so that the hemoglobin level in the blood is also reduced.

The level of hemoglobin in the A2 group has increased due to the effect of giving Balimo immersion water which functions as a therapy for the toxic effects of the Ciu liquor, and Balimo immersion water has flavonoids which are useful as antioxidant compounds, and as a source of protein that can help form hemoglobin in blood cells.

The hemoglobin level of the A3 group which was expected to increase, showed a decrease in hemoglobin levels. This is due to the prolonged administration of the Ciu liquor, which causes more damage to blood cells. This also affects the formation of hemoglobin in blood cells and bone marrow, which becomes inhibited and disturbed. This is explained by Schalm (2010) that the hemoglobin synthesis that occurs in blood cells in the bone marrow will be disrupted and damaged due to the toxic effects caused by ethanol compounds in alcoholic drinks. Aiba et al., (2016) explain that Balimo stems have flavonoid compounds and alkaloids that can be used for antioxidants to repair cells damaged by free radicals.

\section{Hematocrit Value}

The results of statistical tests based on the mean hematocrit value of mice in the treatment groups $\mathrm{A} 1$, $\mathrm{A} 2, \mathrm{~A} 3$ when compared with treatment A0 (control) showed a significant value above $0.05(p>0.05)$ or the results were not significantly different. The results of the analysis of the hematocrit value continue to change based on the group and can be seen in graphs (Figure 3).

Hematocrit Value (\%)

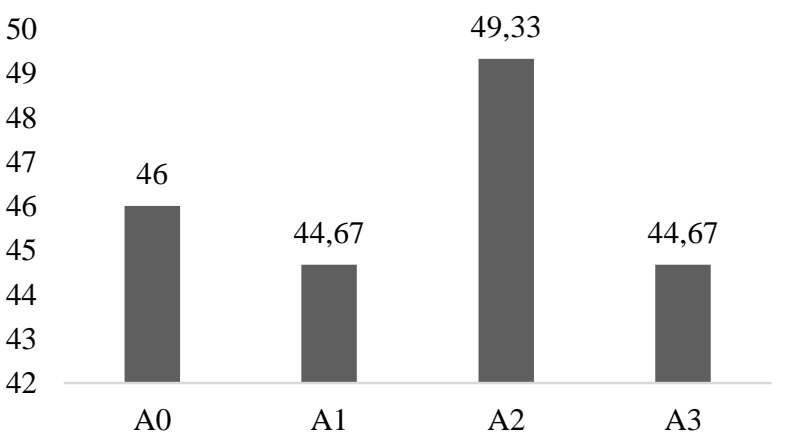

Figure 3. Hematocrit Value.

The mean hematocrit value when compared to the A0 treatment group, the hematocrit value of group A1 decreased due to the toxic effect of Ciu alcoholic drink which resulted in a decrease in the number of erythrocytes and hemoglobin levels, so the hematocrit value also decreased because the hematocrit value was proportional to the erythrocytes count and hemoglobin levels.

The hematocrit value of group A2 increased due to the effect of Balimo immersion water treatment for 2 weeks which functions as an antioxidant against the toxic effects of $\mathrm{Ciu}$ for the previous 2 weeks, this resulted in a return to the condition of the hematological status and was able to increase the erythrocytes count and hemoglobin levels.

Hematocrit value in group A3 showed a decrease in the hematocrit value with the same results as in group A1 because the Ciu was longer than the other groups so that the treatment ability of Balimo immersion water was not able to increase the hemoglobin level, because according to the hemoglobin A3 chart, it was less versus $\mathrm{A} 1$, and shows the same hematocrit value as $\mathrm{A} 1$. This is 
parallel with Rosita, et al. (2015) which states that normal hematocrit values are proportional to the number of erythrocytes and hemoglobin levels. If the erythrocytes count and hemoglobin levels decreased, the percentage of the hematocrit value also decreased.

\section{Total Count of Leukocytes}

The results of statistical tests based on the mean total count leukocytes of rats in the treatment groups A1, A2, A3 when compared with treatment A0 (control) showed a significant value above 0.05 ( $>0.05$ ) or the results were not significantly different. The results of the analysis of the total number of leukocytes still change based on the group and can be seen in graphs (Figure 4).

Total Count of Leukocytes $(\times 103 / \mu \mathrm{L})$

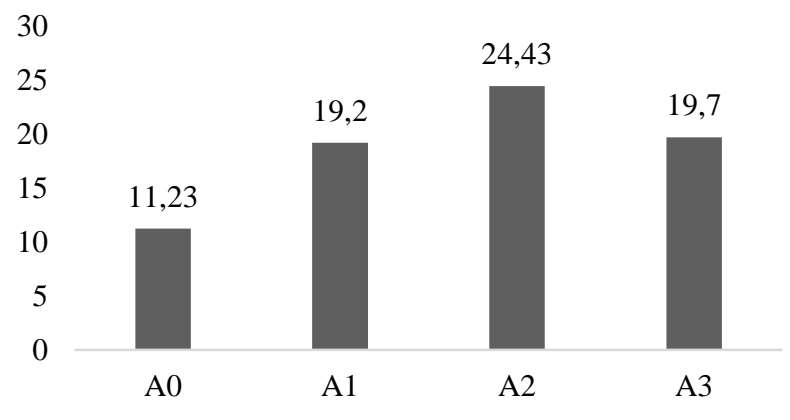

Figure 4. Total Count of Leukocytes.

The mean total count of leukocytes when compared with the treatment group A0, the total count of leukocytes in groups A1, A2, A3 increased. The increase in the total count of leukocytes in group A1 occurs due to the presence of free radical compounds caused by liquor so that the defense system reacts by increasing the count of leukocytes so that foreign compounds including free radicals in the body decrease.

The increase in the total count of leukocytes in group A2 was due to the provision of Balimo immersion water for 2 weeks after Ciu treatment for 2 weeks. Balimo immersion water intake after consuming liquor initially provides a therapeutic effect and eliminates the acid toxicity effect of alcohol to improve the hematological status. Balimo immersion water intake can cause an increase in the total count of leukocytes in the body because, there are anti-inflammatory alkaloid compounds, and can also be active toxin if given excessively so that the leukocyte defense system considers these compounds to be harmful foreign compounds.

The increase in the total count of leukocytes in group A3, which should have shown a result of the total count of leukocytes that is close to $\mathrm{A} 0$, but has not shown a decrease that is close to A0. This is because in the A3 treatment group there was a reaction caused by the Ciu toxic compound given for 4 weeks and the compound in the Balimo immersion water given for the last 2 weeks. Compounds in liquor for 4 weeks caused a toxic effect on the hematological status of the rats, resulting in a significant increase in the total count of leukocytes. After that there was a decrease in the total count of leucocytes due to the provision of Balimo immersion water, however, because the provision of Ciu continued in the last 2 weeks, the function of the Balimo immersed water compound was inhibited, due to the reaction of ethanol compounds from $\mathrm{Ciu}$, and caused the total number of leukocytes not showed signs of a significant decline approaching group A0.

This is in line with the statement of Fitria, (2014) which states that leukocytes are closely related to the body's defense system. Leukocytes in normal conditions are very few, and leukocytes will be increased by pathological conditions. This is following the statement of Aziyah et al. (2014), and Dumeva et al. (2016) which states that alkaloid compounds have active toxic properties when consumed without recommendations. Alkaloids are composed of carbon, hydrogen, and nitrogen which can damage the nervous system, interfere with breathing, and interfere reproductive abilities. Stanley, et al, (2014) also explained that flavonoid compounds can bind and neutralize alcohol so that the total number of leukocytes can decrease. Lenny, (2006) also explains that flavonoid and alkaloid compounds that can bind ethanol compounds reduce the ability to repair cells so that leukocytes help repair and protect the body, especially in areas affected by inflammation.

\section{CONCLUSION}

Based on the results of the study, it was shown that Balimo stem soaking water intake affected the number of erythrocytes, hemoglobin levels, hematocrit value, and the total number of leukocytes in rats that had been given Ciu. Intake of Balimo immersion water can improve the hematological status of rats that have been given Ciu.

Conflict of interest: The authors declares that there are no conflicts of interest concerning the publication of this article.

\section{REFERENCES}

Aiba, S., Manalu, W., Suprayogi, A., \& Maheswari, H. (2016). "Gambaran Nilai Hematologi Tikus Putih Betina Dara pada Pemberian Tombong Kelapa," Acta Veterinaria Indonesiana 4(2): 74-81.

Andasputra, N., \& Julipin, V. (2011). Mencermati Dayak Kanayatn. Institut Dayakologi, Pontianak.

A’tourrohman. (2020). Teknik Menghitung Kadar Hemoglobin Menggunakan Metode Sahli. UIN Walisongo, Semarang. 
Armitage, J. O. (2011). Approach to the Patient with Lymphadenopathy and Splenomegaly. in: Goldman's Cecil Medicine: Twenty Fourth Edition. Elsevier Inc.

Bakhri, S. (2018). Analisis Jumlah Leukosit Dan Jenis Leukosit Pada Individu Yang Tidur Dengan Lampu Menyala Dan Yang Dipadamkan. Jurnal Media Analis Kesehatan 1(1): 83-91.

Bhattacharya, S. \& Zaman, M. K. (2009). Pharmacognostical evaluation of Zanthoxylum nitidum bark. International Journal of PharmTech Research 1(2): 292-298.

BPOM RI. (2014). Topik Sajian Utama: Memiliki Regulasi Minuman Beralkohol di Indonesia. InfoPOM 15(3): 4

Catherine, P. B., Kevin, D. C, Natalie, W., Michael, J. C., \& Jonathan, M. H. (2015). Dietary flavonoids and nitrate: effects on nitric oxide and vascular function. Nutrition Review (74): 216-235.

Dumeva, A., Syarifah \& Fitriah, S. (2016) Pengaruh ekstrak batang brotowali (Tinospora crispa) terhadap kematian larva nyamuk Aedes aegypti. Jurnal Biota 2(2): 166-172.

Fitria, L. 2014. Profil Hematologi Tikus (Rattus norvegicus Berkenhout, 1769) Galur Wistar Jantan dan Betina Umur 4, 6, dan 8 Minggu. Biogenesis: Jurnal Ilmiah Biologi 2(2): 94100.

Gomez, K. A. (2005). Prosedur Statistik Untuk Penelitian Pertanian, edisi kedua. UI Press, Jakarta.

Guyton, A. C., \& Hall, J. E. (2014). Buku Ajar Fisiologi Kedokteran. Edisi 12. Penterjemah: Ermita I, Ibrahim I. Elsevier, Singapura.

Hammer, J. H., Parent, M.C., \& Spiker, D. A. 2018 Global status report on alcohol and health 2018, Global status report on alcohol. WHO, Switzerland

Hartono, R., Soewono, \& Ratnaningsih, T. (2019). Pengaruh Pemberian Alkohol Peroral Terhadap Nilai Mean Corpuscular Volume, Morfologi Eritrosit Darah Tepi dan Normoblas Sumsum Tulang. Jaringan Laboratorium Medis 1(1): 46.

Ifeannyi, O. E., Ndukaku, O. Y., Ndubuisi, O. T., Kalu, O. N., \& Obioma, E. (2014). Some Haematological and Biochemical Parameters of Chronic Alcoholics in Umuahia, Abia State, Nigeria. Research Journal of Pharmaceutical, Biological and Chemical Scienses 5(2): 831-836.

Jain, D., Aggarwal, H. K., Rao, A., Dahiya, S., \& Singla, S. (2016). Hematological spectrum in patients with alcoholic liver cirrhosis: a model of end-stage liver disease score based approach. International Journal of Advances in Medicine 3(2): 234-240.

Katzung, B. G., \& Trevor, A. J. (2015). Pharmacology Examination \& Board Review, 11th Edition, Emergencies in Pediatric Oncology. Cenveo Publisher Services, USA.

King, M. W., (2010). Ethanol metabolism. https://themedicalbiochemistrypage.org/ethanolmetabolism.php. 15 Maret 2020.

Lenny, S. (2006). Senyawa Flavonoida, Fenil Propanoida dan Alkaloida. Karya Ilmiah. Fakultas MIPA Universitas Sumatera Utara, Sumatra Utara.
Lindseth, G. N. (2013). Gangguan hati, kandung empedu, dan pankreas. Dalam: Patofisiologi konsep klinis proses-proses penyakit. Edisi ke-6. EGC, Jakarta.

Nor Aziyah, B., Norain, I., Nor Aimi, A.W., Lim, B.T., Wan Zarina, W.K. \& Siti Nur Amirah Diana, F. (2014). Biopesticidal effect of Tinospora crispa extracts against flea beetles, Phyliotera sinuata ateph. Research Journal of Biotechnology. 9(1).

Nurrahman, N., \& Mariyam, M. (2019). Status Hematologi, Kadar IgG dan IgA Tikus yang Mengonsumsi berbagai Variasi Jumlah Tempe Kedelai Hitam. agriTECH, 39(3): 215.

Oktiyani, N., Fahriyan, F., \& Muhlisin, A. (2017). Akurasi Hitung Jumlah Eritrosit Metode Manual dan Metode Otomatis. Medical Laboratory Technology Journal 3(2): 37.

Raja, R. N. L. \& Hartana, A. (2017). Variasi Morfologi Andaliman (Zanthoxylum Acanthopodium) Di Sumatera Utara. Floribunda 5(7): 258-266.

Riany, R., Pradono, S. A. \& Rahmayanti, F. (2013). Hematology and Blood Chemistry Test Results among Resident in Balai. (4): $1-16$

Rosita, A., Mushawwir, A. dan Latipudin, D. (2015). Status Hematologis (Eritrosit, Hematokrit, Dan Hemoglobin) Ayam Petelur Fase Layer Pada Temperature Humidity Index Yang Berbeda. Student E-Jurnas Unpad 4(1).

Schalm, O. W. (2010). Vetenary Hematology. 6nd Edition. Lea and Febriger, Phidelpia.

Sepsamli, L. \& Jumari, E. P. (2019). Ethnobotany of Balimo (Zanthoxylum nitidum) in the Kanayatn Dayak Community in Tapakng, West Kalimantan. Biosaintifika Journal of Biology \& Biology Education 11(3): 318-324.

Shah, V. H. (2015). Managing alcoholic liver disease. Clinical and molecular hepatology 21(3): 1-12.

Stanley, Veith, \& Wakefield. (2014). Curremt Therapy in Vascular and Endovascular Surgery. Elsivier. USA.

Suryani, Yani, Iman H., Ayu, S., Gilang, D. P. \& Poniah, A. (2013). The effect of nitrogen and sulfur addition on bioethanol solid waste fermented by the consortium of Trichoderma viride and saccharomyces cerevisiae towards dry materials, organic materials, crude protein and nonnitrogen protein. Asian Journal of Agriculture and Rural Development, 3(9) 2013: 622-631.

Van Nguyen, T. H., Tran, T. T., \& Cam, T. I. (2019). Alkaloids from Zanthoxylum nitidum and Their Cytotoxic Activity. Natural Product Communications 14(5): 1-5.

Wilson, D. F. \& Matschinsky, F. M. (2020). Ethanol metabolism: The good, the bad, and the ugly. Medical Hypotheses, (140).

Yousif, Y. B., Sanaa, S., Talal, A., \& Shtywy, A. (2012). Structure-activity relationships regarding the antioxidant effects of the flavonoids on human erythrocytes. Natural Science 4(94): 740-747. 
Table S1. Result of the normality test.

Tests of Normality

\begin{tabular}{|l|r|r|r|r|r|r|}
\hline \multirow{2}{*}{ Variabel } & \multicolumn{3}{|c|}{ Kolmogorov-Smirnov } & \multicolumn{3}{c|}{ Shapiro-Wilk } \\
\cline { 2 - 7 } & Statistic & \multicolumn{1}{c|}{ df } & \multicolumn{1}{c|}{ Sig. } & \multicolumn{1}{c|}{ Statistic } & \multicolumn{1}{c|}{ Df } & \multicolumn{1}{c|}{ Sig. } \\
\hline Erythrocytes number &, 215 & 12 &, 131 &, 935 & 12 &, 442 \\
Hemoglobin level &, 156 & 12 &, 200 &, 953 & 12 &, 676 \\
Hematocrit value &, 136 & 12 &, 200 &, 970 & 12 &, 908 \\
Total leukocytes &, 207 & 12 &, 166 &, 909 & 12 &, 206 \\
\hline
\end{tabular}

*. This is a lower bound of the true significance.

a. Lilliefors Significance Correction

Table S2. Result of the homogeneity test.

Test of Homogeneity of Variances

\begin{tabular}{|l|r|r|r|r|}
\hline \multicolumn{1}{|c|}{ Variabel } & Levene Statistic & df1 & df2 & \multicolumn{1}{c|}{ Sig. } \\
\hline Erythrocytes number & 2,270 & 3 & 8 &, 157 \\
Hemoglobin level & 1,964 & 3 & 8 &, 198 \\
Hematocrit value & 2,013 & 3 & 8 &, 191 \\
Total leukocytes & 2,729 & 3 & 8 &, 114 \\
\hline
\end{tabular}

Table S3. Anova test

\begin{tabular}{|ll|r|r|r|r|r|}
\hline & Variabel & $\begin{array}{c}\text { Sum of } \\
\text { Squares }\end{array}$ & df & $\begin{array}{c}\text { Mean } \\
\text { Square }\end{array}$ & F & Sig. \\
\hline Erythrocytes & Between Groups &, 430 & 3 &, 143 &, 808 &, 524 \\
number & Within Groups & 1,420 & 8 &, 178 & & \\
& Total & 1,850 & 11 & & & \\
\hline Hemoglobin & Between Groups & 3,583 & 3 & 1,194 & 1,031 &, 429 \\
Level & Within Groups & 9,267 & 8 & 1,158 & & \\
& Total & 12,849 & 11 & & & \\
\hline Hematocrit & Between Groups & 43,667 & 3 & 14,556 & 1,456 & \\
Value & Within Groups & 80,000 & 8 & 10,000 & & \\
& Total & 123,667 & 11 & & & \\
\hline Total & Between Groups & 269,576 & 3 & 89,859 &, 789 & \\
Leukocytes & Within Groups & 911,573 & 8 & 113,947 & & \\
& Total & 1181,149 & 11 & & & \\
\hline
\end{tabular}


Table S4. Results of the descriptive data analysis of the treatment.

\begin{tabular}{|c|c|c|c|c|c|c|c|c|c|}
\hline \multicolumn{10}{|c|}{ Descriptives } \\
\hline \multirow{2}{*}{\multicolumn{2}{|c|}{ Variabel }} & \multirow[b]{2}{*}{$\mathrm{N}$} & \multirow[b]{2}{*}{ Mean } & \multirow[b]{2}{*}{$\begin{array}{c}\text { Std. } \\
\text { Deviation }\end{array}$} & \multirow[b]{2}{*}{ Std. Error } & \multicolumn{2}{|c|}{$\begin{array}{l}95 \% \text { Confidence } \\
\text { Interval for Mean }\end{array}$} & \multirow[b]{2}{*}{ Minimum } & \multirow[b]{2}{*}{ Maximum } \\
\hline & & & & & & $\begin{array}{l}\text { Lower } \\
\text { Bound }\end{array}$ & $\begin{array}{l}\text { Upper } \\
\text { Bound }\end{array}$ & & \\
\hline Erythrocytes & $\mathrm{A} 0$ & 3 & 5,10000 & ,400000 & 230940 & 4,10634 & 6,09366 & 4,700 & 5,500 \\
\hline \multirow[t]{4}{*}{ number } & A1 & 3 & 4,96667 & |057735 & ,033333 & 4,82324 & 5,11009 & 4,900 & 5,000 \\
\hline & A3 & 3 & 5,46667 & ,472582 & 272845 & 4,29271 & 6,64062 & 5,100 & 6,000 \\
\hline & A3 & 3 & 5,06667 & ,568624 & ,328295 & 3,65413 & 6,47921 & 4,600 & 5,700 \\
\hline & Total & 12 & 5,15000 & ,410100 & 118386 & 4,88944 & 5,41056 & 4,600 & 6,000 \\
\hline Hemoglobin & $\mathrm{AO}$ & 3 & 15,33333 & 1,159023 & .669162 & 12,45416 & 18,21251 & 14,100 & 16,400 \\
\hline \multirow[t]{4}{*}{ Level } & A1 & 3 & 14,96667 & ,251661 & ,145297 & 14,34151 & 15,59183 & 14,700 & 15,200 \\
\hline & A3 & 3 & 16,23333 & 1,365040 & ,788106 & 12,84239 & 19,62428 & 15,300 & 17,800 \\
\hline & A3 & 3 & 14,83333 & 1,167619 & 674125 & 11,93281 & 17,73386 & 13,800 & 16,100 \\
\hline & Total & 12 & 15,34167 & 1,080790 & 311997, & 14,65497 & 16,02837 & 13,800 & 17,800 \\
\hline Hematocrit & A0 & 3 & 46,00000 & 3,605551 & 2,081666 & 37,04331 & 54,95669 & 42,000 & 49,000 \\
\hline \multirow[t]{4}{*}{ Value } & A1 & 3 & 44,66667 & ,577350 & ,333333 & 43,23245 & 46,10088 & 44,000 & 45,000 \\
\hline & A3 & 3 & 49,33333 & 3,214550 & 1,855921 & 41,34795 & 57,31872 & 47,000 & 53,000 \\
\hline & A3 & 3 & 44,66667 & 4,041452 & 2,333333 & 34,62714 & 54,70619 & 41,000 & 49,000 \\
\hline & Total & 12 & 46,16667 & 3,352972 & 967920, & 44,03629 & 48,29704 & 41,000 & 53,000 \\
\hline Total & $\mathrm{A} 0$ & 3 & 11,23333 & 1,803700 & 1,041367 & 6,75269 & 15,71397 & 9,500 & 13,100 \\
\hline \multirow[t]{4}{*}{ Leukocytes } & $\mathrm{A} 1$ & 3 & 19,20000 & 10,400000 & 6,004443 & $-6,63503$ & 45,03503 & 12,800 & 31,200 \\
\hline & A3 & 3 & 24,43333 & 18,123557 & 10,463641 & $-20,58808$ & 69,45475 & 5,800 & 42,000 \\
\hline & A3 & 3 & 19,70000 & 3,988734 & 2,302897 & 9,79144 & 29,60856 & 17,200 & 24,300 \\
\hline & Total & 12 & 18,64167 & 10,362297 & 2,991337 & 12,05778 & 25,22556 & 5,800 & 42,000 \\
\hline
\end{tabular}

Table S5. Tukey Test.

Multiple Comparisons

\begin{tabular}{|c|c|c|c|c|c|c|c|}
\hline \multirow[b]{2}{*}{ Dependent Variable } & \multirow[b]{2}{*}{$\begin{array}{c}\text { (I) } \\
\text { Perlakuan }\end{array}$} & \multirow[b]{2}{*}{$\begin{array}{c}(\mathrm{J}) \\
\text { Perlakuan }\end{array}$} & \multirow[b]{2}{*}{$\begin{array}{c}\text { Mean } \\
\text { Difference } \\
(\mathrm{I}-\mathrm{J})\end{array}$} & \multirow[b]{2}{*}{ Std. Error } & \multirow[b]{2}{*}{ Sig. } & \multicolumn{2}{|c|}{$95 \%$ Confidence Interval } \\
\hline & & & & & & $\begin{array}{l}\text { Lower } \\
\text { Bound }\end{array}$ & $\begin{array}{l}\text { Upper } \\
\text { Bound }\end{array}$ \\
\hline Erythrocytes Tukey & $\mathrm{A} 0$ & $\mathrm{~A} 1$ & ,133333 & ,343996 & 979 &,- 96826 & 1,23493 \\
\hline \multirow[t]{6}{*}{ Number } & & A3 &,- 366667 & ,343996 & ,718 & $-1,46826$ & ,73493 \\
\hline & & A3 & ,033333 & 343996 & 1,000 & $-1,06826$ & 1,13493 \\
\hline & $\mathrm{A} 1$ & A0 &,- 133333 & ,343996 & ,979 & $-1,23493$ & 96826 \\
\hline & & A3 &,- 500000 & ,343996 &, 504 & $-1,60160$ & ,60160 \\
\hline & & A3 &,- 100000 & ,343996 & ,991 & $-1,20160$ & 1,00160 \\
\hline & A3 & A0 & ,366667 & ,343996 & ,718 &,- 73493 & 1,46826 \\
\hline
\end{tabular}







Table S6. Result of the Tukey \& Duncan test.

\section{Homogeneous Subsets}

Erythrocytes number

\begin{tabular}{|r|r|r|r|}
\hline & & & \multicolumn{1}{|c|}{$\begin{array}{c}\text { Subset for } \\
\text { alpha }=0.05\end{array}$} \\
\cline { 4 - 4 } & Treatment & $\mathrm{N}$ & \multicolumn{1}{c|}{1} \\
\hline Tukey HSD & A1 & 3 & 4,96667 \\
& A3 & 3 & 5,06667 \\
& A0 & 3 & 5,10000 \\
& A3 & 3 & 5,46667 \\
& Sig. & &, 504 \\
\hline Duncana & A1 & 3 & 4,96667 \\
& A3 & 3 & 5,06667 \\
& A0 & 3 & 5,10000 \\
A3 & 3 & 5,46667 \\
Sig. & &, 209 \\
\hline
\end{tabular}

Means for groups in homogeneous subsets are displayed.

a. Uses Harmonic Mean Sample Size $=3,000$.

Hemoglobin Level

\begin{tabular}{|l|l|r|r|}
\hline & & & \multicolumn{1}{|c|}{$\begin{array}{c}\text { Subset for } \\
\text { alpha }=0.05\end{array}$} \\
\cline { 4 - 4 } & Treatment & $\mathrm{N}$ & \multicolumn{1}{|c|}{1} \\
\hline Tukey HSD & A3 & 3 & 14,83333 \\
& A1 & 3 & 14,96667 \\
& A0 & 3 & 15,33333 \\
& A3 & 3 & 16,23333 \\
& Sig. & &, 433 \\
\hline Duncan & A3 & 3 & 14,83333 \\
& A1 & 3 & 14,96667 \\
& A0 & 3 & 15,33333 \\
& A3 & 3 & 16,23333 \\
& Sig. & &, 172 \\
\hline
\end{tabular}

Means for groups in homogeneous subsets are displayed.

a. Uses Harmonic Mean Sample Size $=3,000$.

\begin{tabular}{|l|r|r|r|}
\hline \multicolumn{1}{|c|}{ Hematocrit value } \\
\cline { 4 - 4 } & & & $\begin{array}{c}\text { Subset for } \\
\text { alpha }=0.05\end{array}$ \\
\cline { 3 - 4 } & Treatment & $\mathrm{N}$ & \multicolumn{1}{|c|}{1} \\
\hline Tukey HSD & A1 & 3 & 44,66667 \\
& A3 & 3 & 44,66667 \\
& A0 & 3 & 46,00000 \\
& A3 & 3 & 49,33333 \\
& Sig. & &, 337 \\
\hline Duncan a & A1 & 3 & 44,66667 \\
& A3 & 3 & 44,66667 \\
& A0 & 3 & 46,00000 \\
& A3 & 3 & 49,33333 \\
& Sig. & &, 128 \\
\hline
\end{tabular}

Means for groups in homogeneous subsets are displayed.

a. Uses Harmonic Mean Sample Size $=3,000$.

Total leukocytes

\begin{tabular}{|r|r|r|r|}
\hline & & & \multicolumn{1}{|c|}{$\begin{array}{c}\text { Subset for } \\
\text { alpha }=0.05\end{array}$} \\
\cline { 3 - 4 } & Treatment & $\mathrm{N}$ & \multicolumn{1}{c|}{1} \\
\hline Tukey HSD & A0 & 3 & 11,23333 \\
& A1 & 3 & 19,20000 \\
& A3 & 3 & 19,70000 \\
& A3 & 3 & 24,43333 \\
& Sig. & &, 473 \\
\hline Duncan a & A0 & 3 & 11,23333 \\
& A1 & 3 & 19,20000 \\
& A3 & 3 & 19,70000 \\
& A3 & 3 & 24,43333 \\
Sig. & &, 192 \\
\hline
\end{tabular}

Means for groups in homogeneous subsets are displayed.

a. Uses Harmonic Mean Sample Size $=3,000$. 

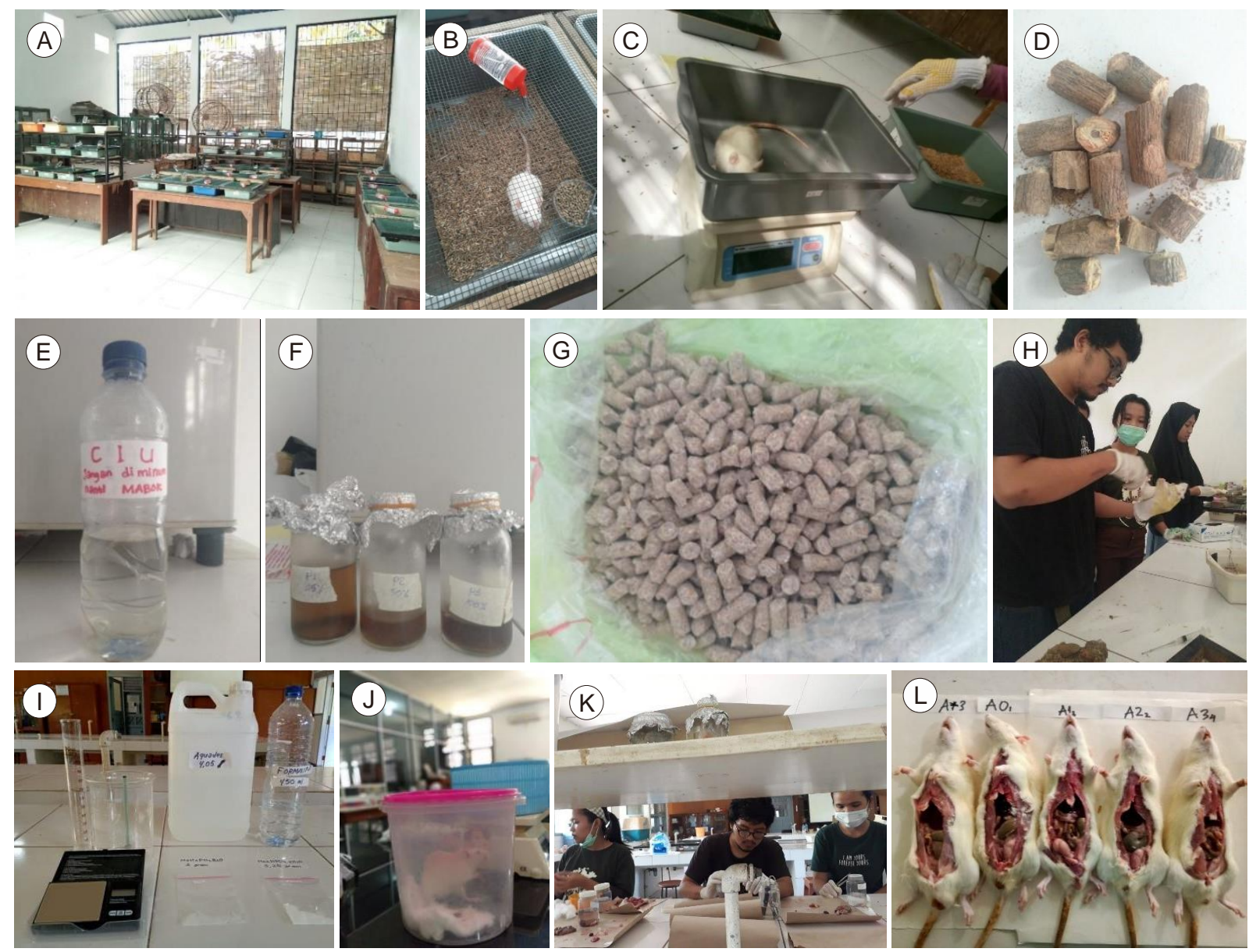

Figure S1. Research photographs (A. Cage; B. Male rats; C. Weighing of test animals; D. Batang balimo; E. Ciu; F. Water immersion of balimo stems; G. Feed for rats; H. Process of treatment; I. 10\% BNF fixative solution; J. Anesthesia process of rats; K. Surgical process; L. Topography of internal organs from test animals) 
THIS PAGE INTENTIONALLY LEFT BLANK 